\title{
VERBAL EMOTIONAL-EXPRESSIVE SENTENCES IN TATAR AND FRENCH LANGUAGES
}

\author{
Baiim Ibragimova ${ }^{1}$ \\ Albina K. Gizatullina ${ }^{2}$ \\ Raushania R. Mingazova ${ }^{3}$ \\ Maria I. Olevskaya ${ }^{4}$
}

\begin{abstract}
The decisive aspect of society development in the modern world is scientific and cultural interaction, cooperation. We hope that this article, devoted to the study of emotionalexpressive syntax in Tatar and French, will make a definite contribution to the development of world scientific and intercultural understanding and cooperation. The problem studied in this article is significant and modern. The comparative study of the syntax of different languages, such as Tatar and French, is extremely important, since it is syntax that is the most valuable source of information about the culture of a particular people, the ideas about morality, the relations to the surrounding world, etc., which becomes the property of linguistic consciousness. This is due
\end{abstract}

to the need for a linguistic analysis of Tatar and French language expressive syntax, as well as to the insufficient study of expressiveness category operation at the syntactic level. Expressive verbal sentences of Tatar and French languages are specialized syntactic means and serve to implement the category of emotional expression. Verbal emotional-expressive sentences in Tatar and French are distinguished by a great variety of structural types. The linguistic specificity of the axiological syntactic units of Tatar and French languages is expressed in their emotional-evaluative lexical content and is associated with the cultural and national characteristics of the studied language bearers. The obtained results make a definite contribution to the

\footnotetext{
${ }^{1}$ Kazan Federal University.

${ }^{2}$ Kazan Federal University.

${ }^{3}$ Kazan Federal University.

${ }^{4}$ Moscow State University. albina27.3@ mail.ru.
} 
development of language expressive picture issue, as well as to communicative linguistics, linguistics and functional stylistics

Keywords: expressive syntax, emotions, emotional evaluation, emotional expression, personal and impersonal forms of the verb, intensifiers.

\section{Introduction}

Modern linguistics is characterized as anthropological: to strive to learn a language in close connection with a person, his consciousness, thinking and practical activity. In other words, linguistics is designed not only to study the language, but also to solve the tasks of mutual understanding between people in all spheres of life.

We conduct the study within the framework of the synchronous comparative-typological analysis of the verbal one-member emotionalexpressive sentences of two genetically unrelated languages, such as the Tatar and French languages. The verb sentences are represented by those in which the main members are expressed by the personal (conjugated) and impersonal (unconjugated) verb form. The impersonal forms of the verb include the participle, the gerund, the name of the action and the infinitive.

\section{Methods}

The work uses linguistic methods and the methods of actual material analysis: comparative, which allows you to determine the similarities and differences between two languages being compared; to determine system matches and the inconsistencies between matched languages; to identify the causes of similarities and differences. The considered means of the comparative method and the model of typological research are purposefully used to determine linguistic universals.

\section{Results and discussion}

Let's consider the verbal singlemember emotional-expressive sentences in the compared languages, expressed by the personal form of the verb. For the Tatar sentence, the absence of the subject is permissible, besides, using the affixes of the person, you can determine a 
subject: барам, укыйм / I go, I read. It is quite difficult to determine a person by personal endings in a French sentence, not with such a precision as in the Tatar language, if possible, because some endings coincide in French language.

Plus bas, la fiche porte une inscription au tampon: recherche, suivie de cette note au crayon: Se trouve au camp de Drancy [2]; Et la petite phrase: "a reintégré le domicile maternel” suppose que l'on savait, au poste de police du quartier Clignancourt, que le père de Dora avait été arrêté le mois précédent [6].

As was mentioned above, verbal emotional-expressive sentences are very common in the Tatar language. It is necessary to name those that are expressed by the verb in a personal form.

(1st person, singular). Considering the sentences formed by the personal verb forms of the 1 st and 2 nd person it should be noted that there is no consensus in the linguistic literature on these sentences. This is due to the fact that the affixes of the first and second person in the Tatar language are decoded as personal pronouns [1]. For example, alam-alamin - min / I take, alasy - - syn / You take, etc. The main member of the
280

verbal emotional-expressive sentence in the Tatar language is expressed by the verb of the 1 st person singular in present, future or past tense of the indicative mood:

Шулай да шикләндм: куркып калмадыммь, оча аламмы мин хәзер? Белмим... [2]; Ләйла! Күрасеняе син янабыз! - дип кычкырдымм. Ләйло башын гына селекте. “Бетеубез шушыммы икән?” - дип уйлап алдым. Эндәшмим [2].

Verbal emotional-expressive sentences can contain interjections and particles, which intensify the content. It is necessary to distinguish the following particles: инде, бит, ич:

Ax, бетәм! Kыстыь! Ax, үләм бит! Ах, уләм!.. Бетәм!.. [4]; Рәхмәт инде Вольдемарга. Эи кушмаса, кайчан күрер идем әле сине? Сагындым үзеңне! Бик сагындым бum!.. [4].

The corresponding French sentences are of two-member sentence type with the subject je:

Si j’avais connu cela plus tôt! [6]. If I had known this before!; Une haine intense brilla dans son regard bleu: - Je vais vous tuer, mon joli! Et si tu savais ce que ça va me faire plaisir! 
[7]; Que je suis contente! [6]. I am so happy!

(1 person plural) The main member of emotionally expressive sentences in the Tatar language can be expressed by the verb of the 1st person plural in the present, future and past tense. These sentences in the Tatar language grammars are considered as one-member [1]:

Эили башласын әле яңуа докторыц.. Күрербез! Алар өйрәнгән анда, калада: кино да театр, театр да кино. Эиласен але мена [2]; Кызганыч... Бүтән андый шәп лакюк. Өлгермддек. Рамнарга башка төс ярамый [4].

The common forms of these sentences may contain interjections, references, particles, and also be accompanied by an adverb:

Эх, калдырдык бит! [2]; Арадан берсе калтыраган тавыш илд: - Ax, харап булдык, ж⿻әмәгать! Мин атларыннан таныйм: бу - ул - дип кыччкырды [2].

The corresponding French sentences are of two-member sentence type:

Nous soyons impossibles, oncle Fred, impossibles! [7]; Ah! si nous pouvions être ainsi! [6]; Et moi aussi, je suis heureuse. Qu'est-ce qu'on s'aime, nous deux! [7].

(2nd person, singular) The following structural type of emotionally expressive sentences in the Tatar language is represented by the verb in the 2nd person, singular as the main member. It should be noted that such a verb form can also formulate a predicate of a two-member incomplete sentence. The difference is manifested in the fact that the actor in single-member sentences is accepted in general, and it appears specifically in incomplete sentences [1]. Both extended and unextended forms of the sentence are used. Unextended sentences are characterized by conciseness. The context is of great importance:

Син, бәлки, мине шәһәргә ябышып яткан “маменькин сынок” дип уйльй торгансыңдыр?.. Ялгышасың! [4].

In addition to interjections, which play an important role, verbal sentences can have particles and nouns as a complement:

- hәй, таптың сүз! - диде ул, кычкырып көлеп [2]; Ул идәннән әйберен альи, оялган-бүртенгән 
кыяфаттәрәк: - Әй Алла, котымны алдыц! - диде [2].

The corresponding French sentences are two-member, as a rule. They are represented by the following types:

Tu es complètement fou! [6]; Bébé, si tu savais ce qu'il m'arrive! [7]; Oh! quelle excellente femme tu es! s'écria-t-il [7].

$\underline{\left(2^{\text {nd }} \text { perdon, plural }\right)}$ The emotional experience is able to be transmitted by a sentence in the Tatar language, the main member of which is expressed by the verb in the 2 nd person, plural. These sentences, in our opinion, are incomplete ones. In verbal sentences, they use both simple and derivative interjections:

Сез яңа кеше. Белмисез! Ә акыл өйрәтәсез... - Ни пычагыма румын теле белән ми черетәсез инде?! - дип, һәммәбезнең фикерен әйтте дә салдь [4] ; Уф, Алла... уф, үтерасез... [4].

In French, the sentences with this structure are represented by twomember sentences. Let's give some examples:

Vous ne vieillissez pas! Vous êtes toujours la même! Comme vous êtes jeune! [6]; Que vous êtes jeune! [7], Vous êtes une fée, Elodine! Vous êtes ma bonne fée! [6].

(3rd prson, singular) The sentences expressed by the verb in 3rd person singular in the present, future and past tense of the indicative mood are also used to express the speaker's emotional state. And these sentences we consider as incomplete ones. Let's present the examples of unextended sentences of a given structure. Verbal emotive sentences contain interjections, which, as a rule, occupy the initial position:

- Гаебе юкльгын раслар өчен, самолет ватылган жсиргә киткәндер. Кайтыр, - диде [2]; Тормыштан артта калган... Картайган!.. [4].

The corresponding French sentences are two-member ones:

Elle est d'un gentil, avec moi! [6]; Agathe est femme - oh, que femme elle est! [6]; Qu'elle a l'air mignon! [7].

(3rd prson, plural) The main member of the verb sentence can be expressed in 3rd person plural in present, future and past tense of the indicative (less often conditional) inclination. As in all previous verbal sentences, the principal member does not define the 
single-member composition of a sentence, since the same verbs can also be used in two-member sentences. The difference, according to M.Z. Zakiev, is that a specific subject is not meant in one-member sentences expressed by the same verbs as in the two-member ones [1]. It is unknown or undefined:

Я Алла! Килделәр! [4]; Сөләйман, тәрәзәне ачып ж⿻ибәреп, балаларча шатланып: - Качалар! дип кычкырдыры [4].

Interjections make the part of verbal emotional-expressive sentence structure in Tatar language. Besides, as was noted above, they are able to be formulated in separate sentences and influence the sentences that are next to them:

\section{Караул! Мальмнь}

талыйлар... Уземне суялар! [2]; - Их, ничек гомер үткәрәләр икән бу таш капчыкта?! - дип уйлана-уйлана, тар, биек там камераның бер бамыннан икенче башына йөрергә тотындыс [2].

As a rule, interjections and interjectional sentences occupy the initial position in a sentence and text [8; 9]. In this paper, the delimitation of interjections and interjectional sentences is carried out according to the following criterion: if after an interjection and corresponding punctuation marks the next word is written with a capital letter, then we have an interjectional sentence; if a word is written with a lowercase letter, then this interjection is not formalized as a separate sentence, but enters into the structure of the subsequent sentence $[3 ; 5 ; 10]$.

As a rule, two member sentences correspond to this type of sentences in French:

Ah! ça... Ils deviennent fou! [6]; S'ils peuvent les détromper! [7]; Ah! voilà comment ils prennent la chose! [7].

We considered verbal sentences expressed by the personal form of the verb. Now we turn to the study of verbal emotional-expressive sentences in the Tatar language, expressed by an impersonal form of the verb.

(-асы/-әсе)
member of emotionally expressive
sentences can be expressed by the
participle ended with -acbl, which is used
to express a strong desire. Although
desire is not considered by us as an
emotion, it is very often accompanied by
the meaning of the impossibility to


implement this desire, regret, sentences:

disappointment, irony, i.e. by emotions.

This circumstance allows us to study this type of sentences.

The main purpose of this form of the verb is the expression of strong desire with various shades of emotional character:

... Мин сине гел тыйнак, гел

айбәт егет итеп күз алдыма китерам. Күрасе иде бер сине! [2]; Дөрес фикерлисен, - диде кыз. Сыйнфый сизамләвен менд дигән. Болар турында солдатларга да сөйләргә кирәк. Эх, дроспраи, укытасы иде сине! Юкса, нәрсә ул дурт классльг земский мәктәп?! Мәсхәрә!.. [4].

The verbal sentences, expressed by the verb ended with -acbl uдe, can have interjections, which, as a rule, occupy the initial position:

Их, тагын бер генә атнага булса да велосипед табып торасы иде дөньяда! Нинди рәхәт булган иде бит узган атнада! [4]; Их, тагын ике гено, һич югы, бер генә көн икәу шул имән “өстәл” артында утырып дәрес хәзерлисе иде доньяда!.. [4].

In French, the following constructions correspond to these
Ah! comme je voudrais être riche! [7]; Oh! comme j'avais envie de le voir! [7]; Si Suleiman était un homme et un père exemplaire [7].

$\underline{(- \text { acы }+ \text { калган })}$ The main member of emotionally expressive sentences can be expressed by the participle ended with $-a c b l$ and the auxiliary word калган and express the regret about what happened or did not happen. This construction is considered by Tatar grammarians as a one-member sentence.

Укымучы буласы калган.
Язасым калган. кичо урманга
барасың калган. It was песеssary to
become a teacher. It was necessary to
write. It was necessary to go to the forest
yesterday.

Verbal emotional-expressive sentences, expressed by the verb of the indicated form, can be extended at the expense of interjections, particles, and other parts of speech:

Их, теге чакта кулга алгач ычкындырасы калмаган икән аны! Кызганган булдым бит! [4]; - Күптән Узебезгә апкайтасы калган икән аны!! Әнә безнең йөртка килү белән хәле рәтләнә бамлады, балакайның!! 
[4].

Such Tatar sentences also correspond to two-member French sentences:

Ah! qu'est-ce qu'on se marrait! Il fallait voir ça! [7]; Il fallait être bête pour vouloir s'évader! [7]; Il fallait fair n'importe quoi pour trouver l'argent! [7].

$\underline{(-\mathbf{I} /-\Pi \text { + бул) }}$ The main member of emotionally expressive sentences can be expressed by the gerund ended with $-b i n /-n$ with the auxiliary verb бул. The grammatical characteristics of the auxiliary verb affect the general grammatical meaning of the whole sentence. This form of the verbal sentence can convey a variety of emotional tones, if the auxiliary verb бул takes the form of a conditional mood. One should distinguish between interjections, references, particles, and others as the lexical means of these sentences emotional content increase. The structure of these sentences can also have the auxiliary verb $и к ә н$ :

Валя хатны ерткалап очырып ж⿻ибәрде. - И-и, жүүләр кызз!.

Шулай ансат кына котылып булса! [4]; - Василий, куренмə! Облава бу!.. Эx, берәр сәгатькә тоткарлап булса! [2].

They also correspond to twomember French sentences:

Oh! si tu avais pu continuer dans ta vraie voie, la sculpture [7]; Si tout le monde pouvait y aller! [7]; S'il avait pu lire dans le coeur d'Adéline! [6].

$\underline{(-\mathbf{y} /-\mathbf{S})}$ The main member of emotionally expressive sentences in Tatar language can be expressed by action name. The name of an action denotes an action (state, process, etc.) in the most general form, irrespective of inclination and time. There are primary and secondary action names. The primary ones are formed from the verbal stems by affixing the affixes $y /-Y$, less often $-u,-b l u /-e w$. Primary action names possess all the grammatical features of the noun (categories of case, number, affiliation), as well as some grammatical features of the verb (categories of voice, aspect, characteristics of an action). Emotionalexpressive sentences, expressed by an action name, may by unextended. Here the context and the graphic image of intonation play an important role. The distributors of these sentences are interjections, which occupy mainly the 
initial position:

Револючия биргән иректән көлүме бу? Көлу! Димәк, латылиларны акылга утыртырга [2]; Бар, бар, Ибрай абый, кире йөгер, стариинань чакырыгыз! Yтереш! [2].

The secondary names of an action are formed from all involved forms on ган/-гән, for example, көлгәнлек, уйлаганлькк / laughter, thoughts and others. The secondary names of the action are used in the language quite rarely according to our observations, so we do not consider them in detail.

The following sentences correspond to them in French:

Comment tu peux dire ça? [7]; Comment, ventrebleu, voyage! [6].

\section{Conclusions}

Verbal sentences are presented in two languages unevenly. In Tatar language, verbal sentences are actively used, the main member of which is expressed by the personal and impersonal form of a verb. Verbal constructions without a subject for the French language are not characteristic. The regular systematically confirmed
286 reproducibility of emotionally expressive verbal sentences confirms the main functional purpose of these units, namely - to express the speaker's expressive attitude to the fact of objective reality.

\section{Summary}

This work is related to the study of emotion expression problem in the language. The analysis of emotionally expressive verbal sentence structures in Tatar and French allows us to state that the functional class of exclaims, which intensifies emotional significance, is an important characteristic of these sentences. All of them act in emotionalexpressive sentences as secondary functions and take an initial position, as a rule.

\section{ACKNOWLEDGEMENTS}

The work is performed according to the Russian Government Program of Competitive Growth of Kazan Federal University

\section{References}

Zakiev M.Z. Tatar grammar: 3 volumes. - Syntax. III v. - Kazan: Tat. publishing house, 1992. - $183 \mathrm{p}$. 
Kamal G. Безнең шәһәрнең серләре: Пьесалар // Әсәрләр: 3 т. - I т. - Kazan: Тат. кит. нәшр., 1978. - 406 б.

Malinovich Yu.M. Expression and sentence meaning / The problems of emotional-expressive syntax. - Irkutsk: Publishing House of Irkutsk University, 1989. - $214 \mathrm{p}$.

Минский Г. Яшенле яңгыр. - Казан: Тат. кит. нәшр., 1976. - 367 б.

Abdullina, L.R., Gizatullina, A.K., Migazova, R.R. Lexical and semantic potential of emotionally expressive sentences in the Tatar and French languages // Journal of Language and Literature. Vol. 6, № 2, pp. 276-278.

Amette J.-P. Province. - Paris: Seuil, 1995. - 243 p.

Belletto R. Sur la terre comme au ciel. Paris, 1995. - 329 p.

Khabibullina, L.F., Vassilieva, V.N. Interaction des idées nationales dans les littératures anglaise et française du XXe siècle (S. Maugham, R. Gary) // Journal of Language and Literature. Vol. 5, № 1, pp. 55-60.

Sadykova, A.G., Aleeva, G.Kh. The ways of expressing objective modality // Life Science Journal, 2014, Volume 11, Issue 9, pp. 393-395.

Zamaletdinov, R.R., Faizullina, G.C. Metaphorization of mythonyms as the way of a person secondary nomination in the Siberian dialects of tatar language // Journal of Language and Literature, Volume 6, Issue 2, 2015, pp. 59-63 